\title{
Long-Term Effects of Simulated Acid Fog on Visible Injury, Growth, Chlorophyll and Nitrogen Content of Japanese Cedar, Red Pine and Beech Seedlings
}

\author{
Saubhagya SILwal, Masatoshi AOKI and Katsutoshi HORIE \\ United Graduated School of Agricultural Science, Tokyo University of Agriculture and \\ Technology, 3-5-8 Saiwai-cho, Fuchu, Tokyo 183-8509, Japan
}

(Received September 3, 2003)

\begin{abstract}
Seedlings of three tree species, Japanese cedar, red pine and beech, grown in plastic green houses were subjected to a simulated acid fog adjusted to $\mathrm{pH}$ values of 2, 3 and 4 and to distilled water (the control), during the growing season from 1998 to 2001, and effects on visible injury, growth, foliage chlorophyll and nitrogen contents were studied. In cedar and pine, an increase in total dry weight (TDW) was accelerated by acid fog of $\mathrm{pH} 2$ and $\mathrm{pH} 3$ with increasing duration of treated years, although a trend of growth inhibition of TDW was observed in beech. The stimulated growth in cedar of $\mathrm{pH} 2$ and $\mathrm{pH} 3$ plots resulted in death of 29 to $45 \%$ of plants. Foliage nitrogen and chlorophyll content in beech were severely affected than in cedar and pine. On the other hand, foliar injury in pine and cedar by acid fog exposure was higher in lower $\mathrm{pH}$ plots and the injury increased with increasing duration of treated years. In contrast, in beech, the injury increased with the decreasing acid fog $\mathrm{pH}$, but wasn't accelerated by increase in duration of treated years. Thus, response of tree seedlings to simulated acid fog was found to be quite complex depending on species and duration of treated years.
\end{abstract}

Keywords : acid fog $\mathrm{pH}$, foliage chlorophyll to nitrogen content ratio, injury index, total dry weight

\section{INTRODUCTION}

Forest decline is one of the serious global environmental problems. As tree growth is a result of multiple interactions of physiological processes influenced by an inherited genetic constitution, ambient environment and age, the forest decline may be attributed to various natural and anthropogenic factors. The causes of the forest decline have been reported elsewhere (Schutt and Cowling, 1985) which include climatic stress, biotic impacts, atmospheric pollution, mineral deficiency, excessive nutrient availability and soil acidification. Among them, acidic deposition is taken as one of the causes. The effects of acidic deposition on plant growth are strongly dependent on the plant species, biological and physio-chemical characteristics of soils (Ashenden and Bell, 1988; Kytoviita et al., 1990 ; Back et al., 1994). There are various reports concerning the impact of acidic deposition on vegetation from various viewpoints (Abouguendia and Baschak, 1987 ; Treshow and Anderson, 1989; Turner and Tingey, 1990 ; Fan and Wang, 2000 ; Aboal et al., 2001 ; Momen et al., 2002; Thelin et

Corresponding author: Saubhagya Silwal, fax : +81-42-367-6078, e-mail : silwal@cc.tuat.ac.jp 
al., 2002).

Effects of acid fog on forest decline are matter of worldwide concern. Based on experimental results with simulated acid fog or acid mist, the potential effects on spruce seedlings include : foliar injury and growth response (Leith et al., 1989 ; Jacobson et al., 1990) ; cuticular wax production and leaf wettability (Percy et al., 1986 ; Boyce et al., 1991 ; Jagels et al., 2002); frost hardiness and winter injury (Cape et al., 1991) ; photosynthesis and stomatal conductance (Eamus and Fowler, 1990); cellular membrane calcium levels (Jiang and Jagels, 1999).

The objective of the present study is to find out long-term effects of simulated acid fog on three tree species. In this experiment, 2-year-old seedlings of cedar, pine and beech were exposed to three $\mathrm{pH}$ levels of simulated acid fog during four consecutive growing seasons, and the effects on visible foliar injury, growth and chlorophyll and nitrogen content of leaves are investigated.

\section{MATERIALS AND METHODS}

1. Plant materials. Three Japanese tree species, that is Japanese cedar (Cryptomeria japonica D. Don), red pine (Pinus densiflora Sieb. et Zucc.) and beech (Fagus crenata Blume) were selected for the experiment. The soil which is known as Kanto loam used in this experiment was taken from uncultivated part $(30 \pm 20 \mathrm{~cm}$ soil depth) at the campus field in Fuchu, Tokyo. The soil was air-dried, sieved (mesh size : $5 \mathrm{~mm}$ ) and immediately used for the experiment. Nitrogen content of the soil was $1.13 \mathrm{~g}$ total $\mathrm{N} / \mathrm{kg}$ dry soil with $\mathrm{pH}$ value 5.93 $(\mathrm{KCl})$. No fertilizer was added to the soil before and throughout the experiment.

2. Experimental design. A plastic green house, $8 \mathrm{~m}$ long by $2.5 \mathrm{~m}$ wide, was constructed and divided into three compartments for the three different acid fog treatment plots. Another plastic green house, $3 \mathrm{~m}$ long by $2.5 \mathrm{~m}$ wide, was constructed separately for control treatment plot so as to avoid the effect from acid fog treatment plots. The plastic green houses were covered by plastic film on the top only. Below the top plastic coverage, double layers of mesh-net (black and white mesh-net) which reduced radiation reaching inside the house to about $60 \%$ of full sunlight, was used as shade to prevent air temperature rise. The plastic film on the top and the mesh-nets protected plants from rain, full sunlight and wind. As for the side walls thin mesh-net (white) was used so as to allow the air to pass through freely. This walling allowed inside environment to be close to ambient meteorological condition. Air temperature inside the plastic green house was recorded continuously using the thermorecorder (T\&D Corp., model: TR-71). As shown in Fig. 1, the monthly maximum air temperatures were 30,29 and $29^{\circ} \mathrm{C}$ in 1999,2000 and 2001 , respectively, and that of minimum temperatures were 4 and $7^{\circ} \mathrm{C}$ in 2000 and 2001 , respectively.

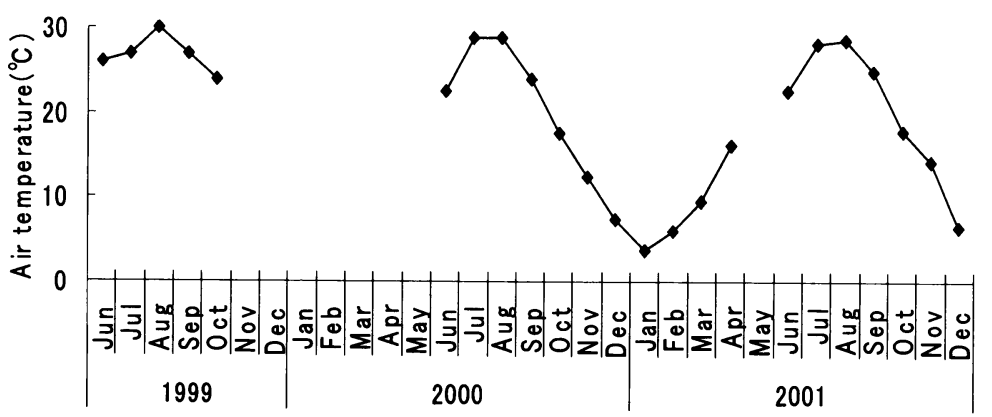

Fig. 1 Average monthly temperature inside the plastic green house in 1999, 2000 and 2001. 


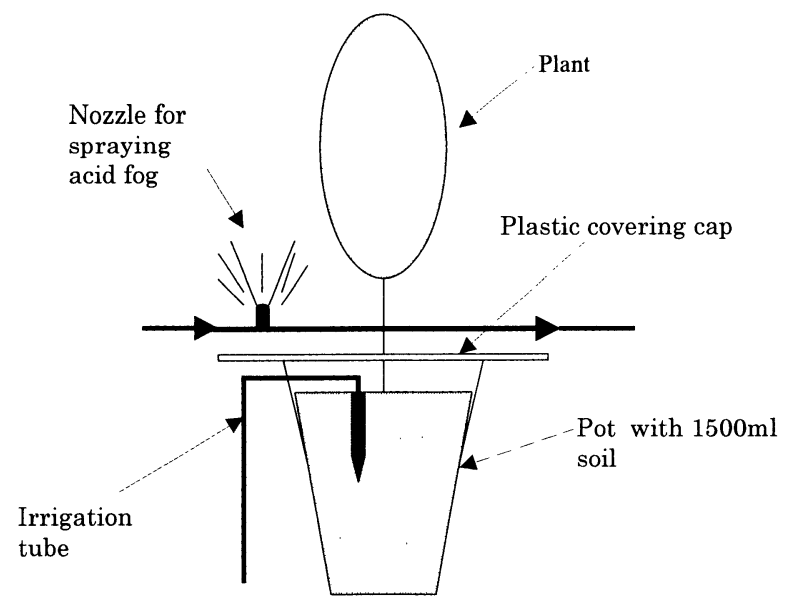

Fig. 2 Schematic diagram of the potted plant and location of the nozzle.

The 2-year-old seedlings were planted in 1/10,000 a Wagner pot with soil volume of 1,500 $\mathrm{ml}$ in the end of April in each year, and were immediately placed inside the plastic green house. As shown in Fig. 2, the surface of each pot was covered with plastic film to prevent from the contamination of soil by direct acid fog deposition and trunk throughall of acid solution. Seedlings were irrigated homogeneously with about $100 \mathrm{ml}$ of tap water each day $(15 \mathrm{~min} /$ day). For irrigation, plastic tubes were installed in each pot which evenly irrigated the soil (see Fig. 2). Twenty healthy seedlings of uniform size were selected for each species and exposed to simulated acid fog. The solution of $\mathrm{pH} 1.5$ was formulated with the mixture of $0.016 \mathrm{~N}$ nitric acid, $0.06 \mathrm{M}$ sodium chloride and $0.021 \mathrm{M}$ ammonium sulphate at room temperature $\left(25^{\circ} \mathrm{C}\right)$. The chemicals used in this experiment were obtained from Wako Pure Chemicals Industries, Ltd. The solution was then adjusted to three acid fog solutions of $\mathrm{pH} 2, \mathrm{pH} 3$ and $\mathrm{pH} 4$ by adding required amount of distilled water. Therefore, $\mathrm{pH} 2$ solution contained 0.032 $\mathrm{N}$ nitric acid, $0.042 \mathrm{M}$ sodium chloride and $0.012 \mathrm{M}$ ammonium sulphate, $\mathrm{pH} 3$ solution contained $0.0032 \mathrm{~N}$ nitric acid, $0.0042 \mathrm{M}$ sodium chloride and $0.0012 \mathrm{M}$ ammonium sulphate, and $\mathrm{pH} 4$ solution contained $0.00032 \mathrm{~N}$ nitric acid, $0.00042 \mathrm{M}$ sodium chloride and $0.00012 \mathrm{M}$ ammonium sulphate. Control plot was also prepared with distilled tap water. Seedlings were exposed to simulated acid fog during four consecutive growing seasons in 1998, 1999, 2000 and 2001. Before the start of the acid fog exposure experiment in the years 1999, 2000 and 2001, twenty seedlings of 2-year-old were newly added to each treatment plot and each species in May. Every treatment plots were exposed to about $2 \mathrm{~mm} /$ day in precipitation amount of each simulated acid fog during daytime for $30 \mathrm{~min}$ on weekdays from June to October. The total acid fog treatment days were 105, 100, 110 and 94 days in 1998, 1999, 2000 and 2001, respectively. Therefore, total acid fog applied in 1998, 1999, 2000 and 2001 were 210 $\mathrm{mm}, 200 \mathrm{~mm}, 220 \mathrm{~mm}$ and $188 \mathrm{~mm}$, respectively.

As shown in Fig. 3, acid fog were applied by high pressure pump (KARCHER Co., Ltd., Germany, model : HD $525 \mathrm{~S}$ ) with specially designed nozzles which created fog of $c a .18 \mu \mathrm{m}$ mean diameter. In order to maintain the constant pressure to generate fog of $c a .18 \mu \mathrm{m}$, excess solutions were returned to the respective tanks. A pump was arranged for each treatment plot and the solution for spraying were supplied from separate tanks (capacity of 300 L) filled with solution of respective simulated acid fog including $\mathrm{pH} 5.6$ solution for control plot. Each compartment was fitted with 6 nozzles placed on the equal distance from each other which provided the uniform amount of the acid fog to the plants. The amount of acid 

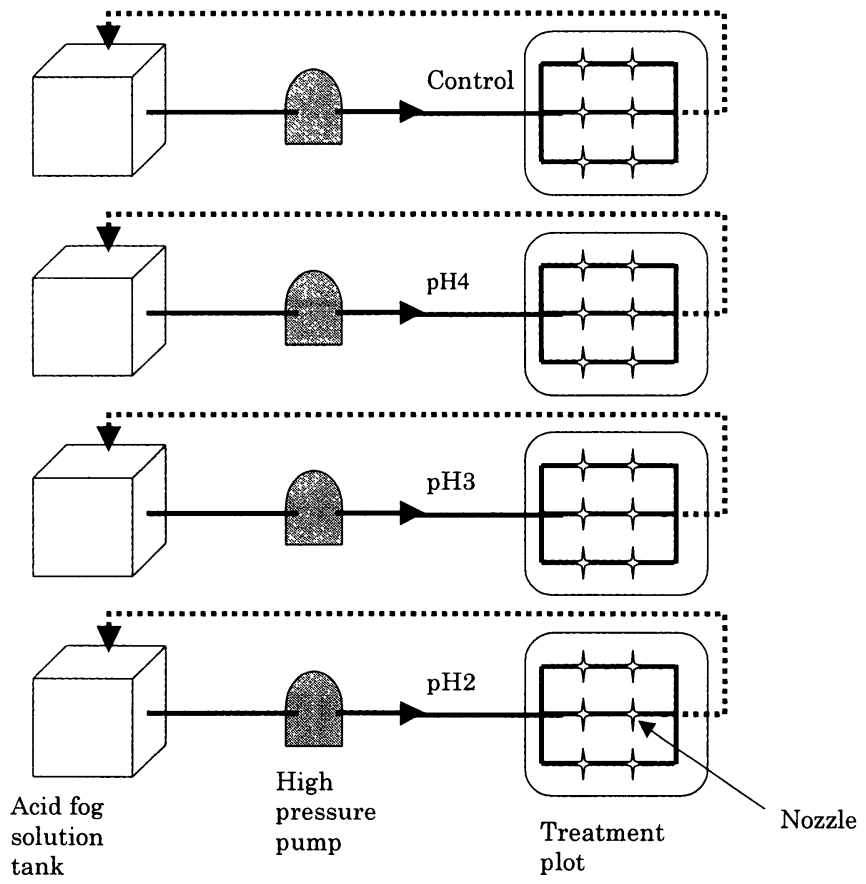

Fig. 3 Schematic diagram of simulated acid fog exposure experiment.

fog exposure, $2 \mathrm{~mm} /$ day, was controlled by adjusting valve fitted at the end of each pipe.

At the end of the treatment in each year, 5 seedlings in each treatment and each species were harvested for growth and element analyses. During winter the remaining of the seedlings were grown in the same green house without the acid fog treatments until the following year's experiment.

\section{MEASUREMENTS}

\section{Growth parameters}

At the end of treatment in each year 5 seedlings of each tree species were harvested for the measurement of total dry weight and determination of the dry weight of each organ. The plant organs were oven dried at $70^{\circ} \mathrm{C}$ for one week, and dry weight of each organ was measured.

\section{Foliage chlorophyll and nitrogen content measurements}

Foliage chlorophyll content was determined at the end of the experiment in each year. At first, fresh leaves were sampled from each treatment, and their chlorophyll a (chl a) and b (chl b) were extracted with ethanol : acetone: water in the ratio $45 \%: 45 \%: 10 \%$. Then their light absorptions were measured by UV-1200 spectrophotometer (Shimadzu). Finally, chl a and chl $b$ were calculated according to the given formulas by Arnon (1949), and total chlorophyll content (Chl) was calculated as the sum of chl a and chl b. The dried leaf materials were grinded, and nitrogen content was measured with $\mathrm{NC}$ analyzer (Sumitomo Chemicals, Sumigraph NC-80) and data recorder (Shimadzu, Chromatopac C-R6A). 


\section{Visible injury measurement}

At the end of the 2000 and 2001 experiments, visible injury was observed for all seedlings. According to degree of visible injury of leaves attached on each seedling, a degree $(0:$ healthy, $1:$ to more than $50 \%$ of injured leaves, $2:$ to more than $75 \%$ of injured leaves and $3:$ dead) was given to each plant seedling. We defined the degree as Injury Degree. The average visible injury degree which is named here as Injury Index was calculated using the following formula :

$$
\text { Injury Index }=\frac{\sum(\text { Injury Degree } \times \text { mumber of plants })}{\text { total number of plants }}
$$

\section{Data analysis}

All statistical tests were performed with SPSS for Windows, version 10.0. The differences between the different treatments were tested by Duncan's multiple range test $(p>$ 0.05). In this experiment, before the start of the acid fog exposure experiment in the years 1999, 2000 and 2001, twenty 2-year-old seedlings were newly added to each treatment plot and each species in May.

After the plant sampling in 1999, 2000 and 2001 all measured data of total dry weight, foliage chlorophyll and nitrogen content were grouped into 1 to 4-year-treatment. However, for visible injury analysis, data were analyzed only from 2000 and 2001 experiments. Visible injury calculated as Injury Index was also averaged by same duration of treated years by grouping into 1 to 4-year-treatment.

In this paper, abbreviations $\mathrm{C}, \mathrm{P}$ and $\mathrm{B}$ represent cedar, pine and beech, respectively. Abbreviation C98(4), for example, represents cedar seedlings of 4-year-treatment which were started to expose in June 1998. Abbreviations for other plant species, started year of the exposure and duration of treated years were expressed accordingly. Numerical symbols in all graphs presented here indicate number of treated years. Thus, symbols in figures, e.g. $1: n=$ $3, \mathrm{C}<\mathrm{pH} 3<\mathrm{pH} 4<\mathrm{pH} 2^{*}$, include information in the following order : number of treated years : $n=$ number of measured data, values of each treatment shown in ascending order. Asterisk indicates significant difference at 0.05 level.

\section{RESULTS}

\section{Growth}

\subsection{Pine}

In pine, TDW of 4-year-treatment (P98(4)) increased with decreasing acid fog pH (Fig. 4, Fig. 5). Specially, $\mathrm{pH} 2$ plot showed significantly high TDW in comparison to the control plot, indicating enhanced growth of pine in low $\mathrm{pH}$ plot. Trunk dry weight also showed the similar trend, but for rest of the organs no such trend was found. TDW data in Fig. 5A were averaged by same duration of treated years, and values relative to the control plots (Fig. 5B) were calculated to determine the average trend of effects by increase in duration of treated years. TDW of 1 and 2-year-treatment in acid fog plots tended to decrease than those of control plots (Fig. 5B) but wasn't significantly affected. Seedlings of 3-year-treatment in all acid fog plots showed a trend of increasing growth but statistical significance wasn't detected.

\subsection{Cedar}

Comparing to the control, $\mathrm{pH} 3$ plot yielded significantly large TDW in 4-year-treatment (C98(4)), but decreased in other acid fog plots (Fig. 4, C98(4), Fig. 5). Among the individual organs, dry weight in late year needle of $\mathrm{pH} 3$ plot had significantly enhanced growth (Fig. 4). As seen in Fig. 5B, TDW of 1 and 2-year-treatment showed no remarkable change in compari- 

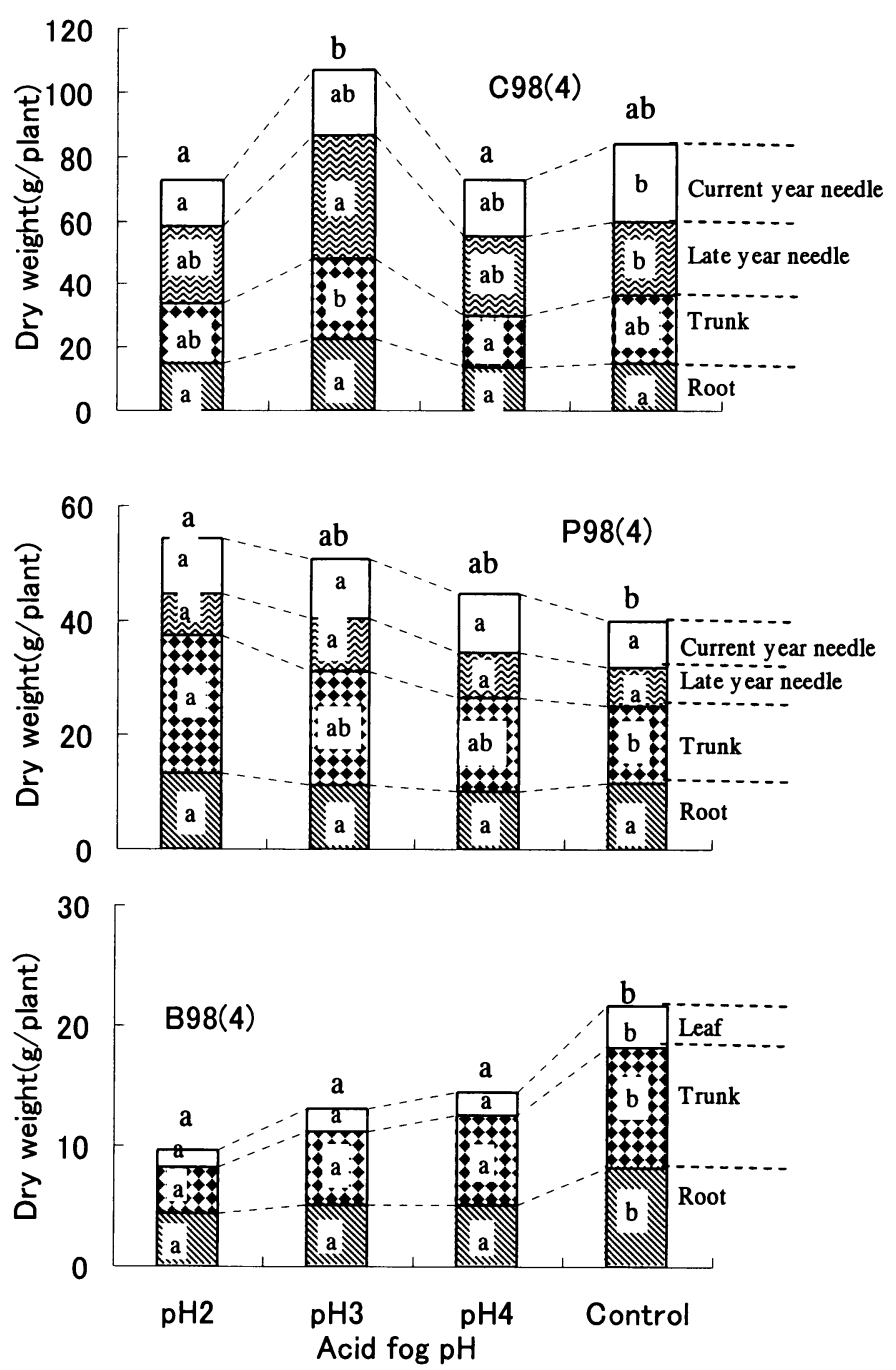

Fig. 4 Total dry weight of each organ in cedar, pine and beech (4-year-treatment) sampled in 2001 experiment. Each plot is the mean of four determinations. Significant differences are designated by different letters based on Duncan's multiple range test $(p>0.05)$.

son to the control plots, except $\mathrm{pH} 3$ plot of 2-year-treatment which showed relatively small yield but wasn't significant as can be seen in Fig. 5A. However for 3-year-treatment, all acid fog plots showed a trend of enhanced TDW, and were significantly high in $\mathrm{pH} 2$ or $\mathrm{pH} 3$ plot. Thus, the effects of acid fog treatments on TDW tended to differ from that of pine mentioned above.

\subsection{Beech}

In contrast to pine and cedar, TDW of beech (Fig. 5A) as well as dry weight of each organ decreased significantly than the control plot in all acid fog plots (Fig. 4, B98(4)). All treatment plots showed an inhibiting trend in TDW regardless of the duration of treated years, except pH 3 plot of 3-year-treatment (Fig. 5B), but wasn't significant as can be seen in Fig. 5A. 

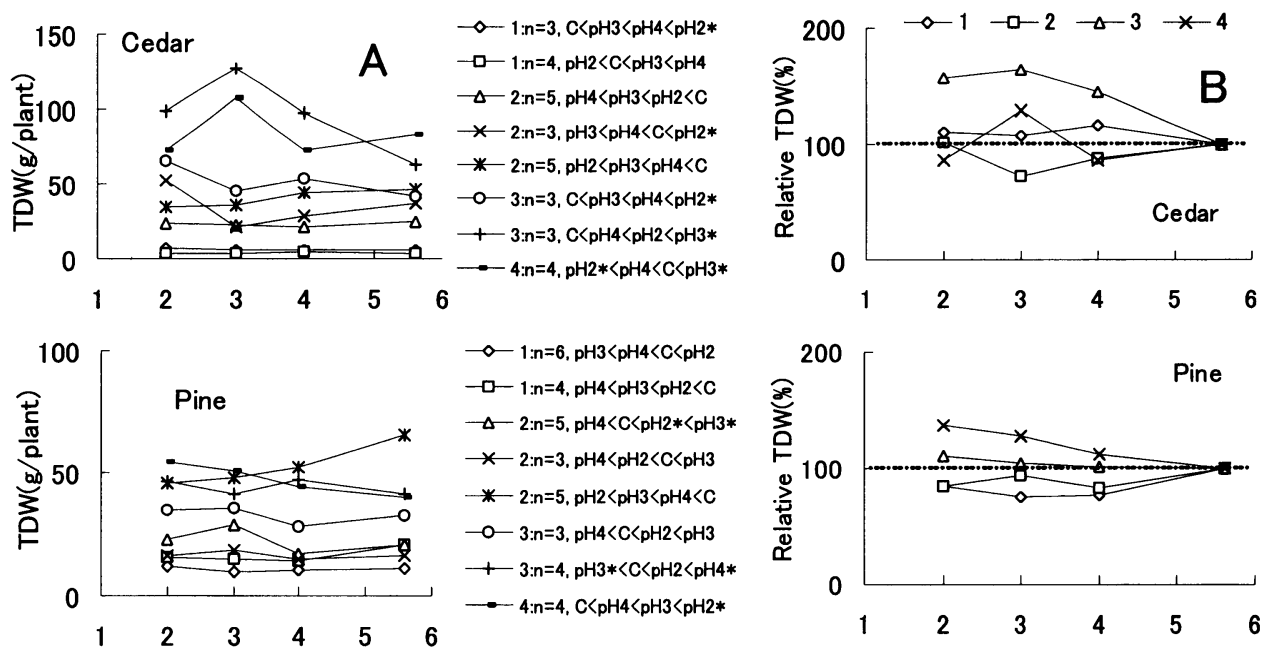

$\multimap 1: \mathrm{n}=6, \mathrm{pH} 3<\mathrm{pH} 4<\mathrm{C}<\mathrm{pH} 2$

$\rightarrow-1: \mathrm{n}=4, \mathrm{pH} 4<\mathrm{pH} 3<\mathrm{pH} 2<\mathrm{C}$

$\triangle 2: n=5, p H 4<C<p H 2 *<p H 3 *$

$\rightarrow 2: \mathrm{n}=3, \mathrm{pH} 4<\mathrm{pH} 2<\mathrm{C}<\mathrm{pH} 3$

$\rightarrow-2: n=5, \mathrm{pH} 2<\mathrm{pH} 3<\mathrm{pH} 4<\mathrm{C}$

$-0-3: n=3, \mathrm{pH} 4<\mathrm{C}<\mathrm{pH} 2<\mathrm{pH} 3$

$+3: \mathrm{n}=4, \mathrm{pH} 3 *<\mathrm{C}<\mathrm{pH} 2<\mathrm{pH} 4 *$

$-4: n=4, C<\mathrm{pH} 4<\mathrm{pH} 3<\mathrm{pH} 2 *$
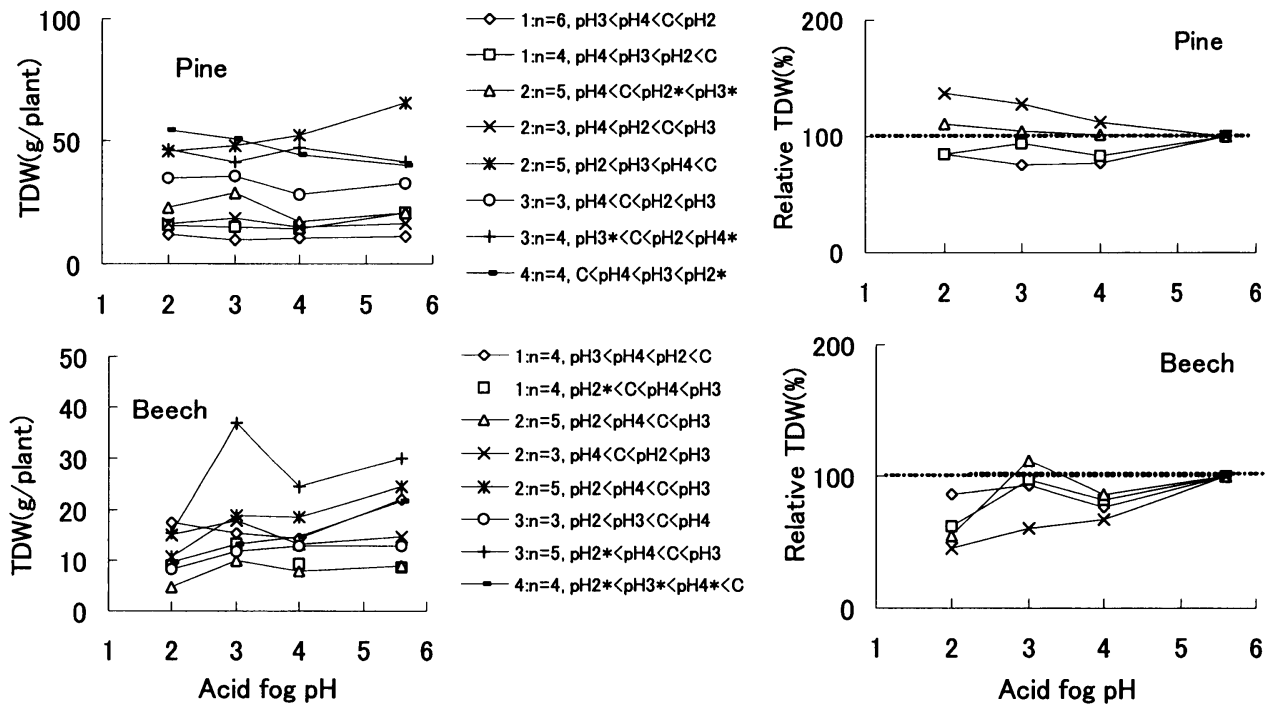

Fig. 5 Effects of simulated acid fog on total dry weight (TDW) of three tree seedlings exposed to simulated acid fog of different $\mathrm{pH}$ levels. Left three figures (A) for cedar, pine and beech are the results of 1999 (100 days), 2000 (110 days) and 2001 (94 days) experiments. Numbers of samples $(n)$ are shown after the each legend symbol. ${ }^{*}$ represents significant difference at 0.05 level by Duncan's multiple range test. Right three figures (B) for cedar, pine and beech are the average relative TDW to those of the control plots. Numerals in the legend represent the year of treated duration.

\section{Foliage chlorophyll content}

\subsection{Pine}

Figure 6B shows average total chlorophyll content for all species relative to the controls calculated from data in Fig. 6A. Relative total chlorophyll contents of all acid fog plots in 2-year-treatment showed significantly large values than in other duration of treated years (Fig. 6B). And total chlorophyll content in only $\mathrm{pH} 2$ plots of 3-year-treatment was significantly low in comparison to the control. Chlorophyll content in acid fog plots of 4-year-treatment didn't show significant change than in control plot. Finally, it can be said that total chlorophyll content in pine tended to increase until 3-year-treatment and switched to a decreasing trend for 4-year-treatment except $\mathrm{pH} 2$ plot.

\subsection{Beech}

Chlorophyll contents in all acid fog plots of 1 and 4-year-treatment were significantly decreased than in control plot. However, for 3-year-treatment only $\mathrm{pH} 3$ plot had significantly high value which may be attributable to an exceptional large value shown in Fig. $6 \mathrm{~A}$ by the symbol ' $X$ '. Chlorophyll content of 3-year-treatment also showed a decreasing trend but was significant only in pH 2 plot (Fig. 6B). Thus, it became obvious that the 

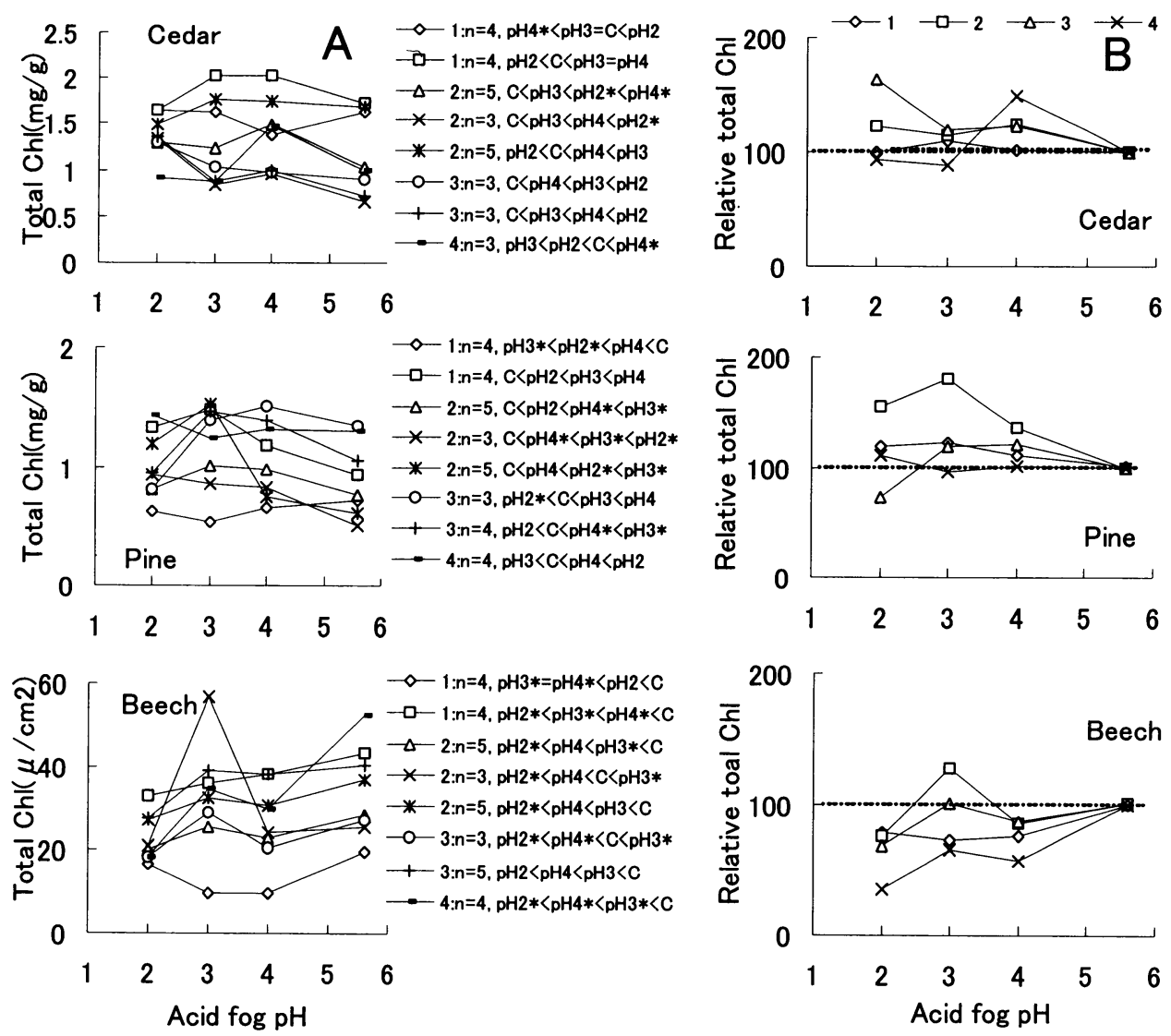

Fig. 6 Effects of simulated acid fog on foliage chlorophyll concentration of three tree seedlings exposed to simulated acid fog of different $\mathrm{pH}$ levels. Left three figures (A) for cedar, pine and beech are results of 1999 (100 days), 2000 (110 days) and 2001 (94 days) experiments. Numbers of samples $(n)$ are shown after the each legend symbol. * represents significant difference at 0.05 level by Duncan's multiple range test. Right three figures (B) for cedar, pine and beech are the average relative total chlorophyll shown by same duration of treated year. Numerals in the legend represent the year of treated duration.

increase in duration of treated years clearly decreased chlorophyll content in beech leaves.

\subsection{Cedar}

Total chlorophyll content of 1-year-treatment didn't show any change by acid fog treatment comparing to the control plot. Total chlorophyll content showed increasing trend in 2 and 3-year-treatment than in 1-year-treatment but data weren't significant except for $\mathrm{pH} 2$ plot. The maximum relative total chlorophyll content for 2 and 3-year-treatment also occurred in $\mathrm{pH} 2$ plots. However, for 4-year-treatment, the relative value (Fig. 6B) of total chlorophyll content decreased in $\mathrm{pH} 2$ and $\mathrm{pH} 3$ plots which weren't significant, although $\mathrm{pH} 4$ plot had significantly large value (see also Fig. 6A). Thus, total chlorophyll content in cedar didn't show clear trend until 4-year-treatment.

\section{Foliage chlorophyll and nitrogen ratio}

As nitrogen is one of the main components of chlorophyll, for the growing plants, foliage chlorophyll nitrogen content relationship shows positive correlation. For the further analy- 

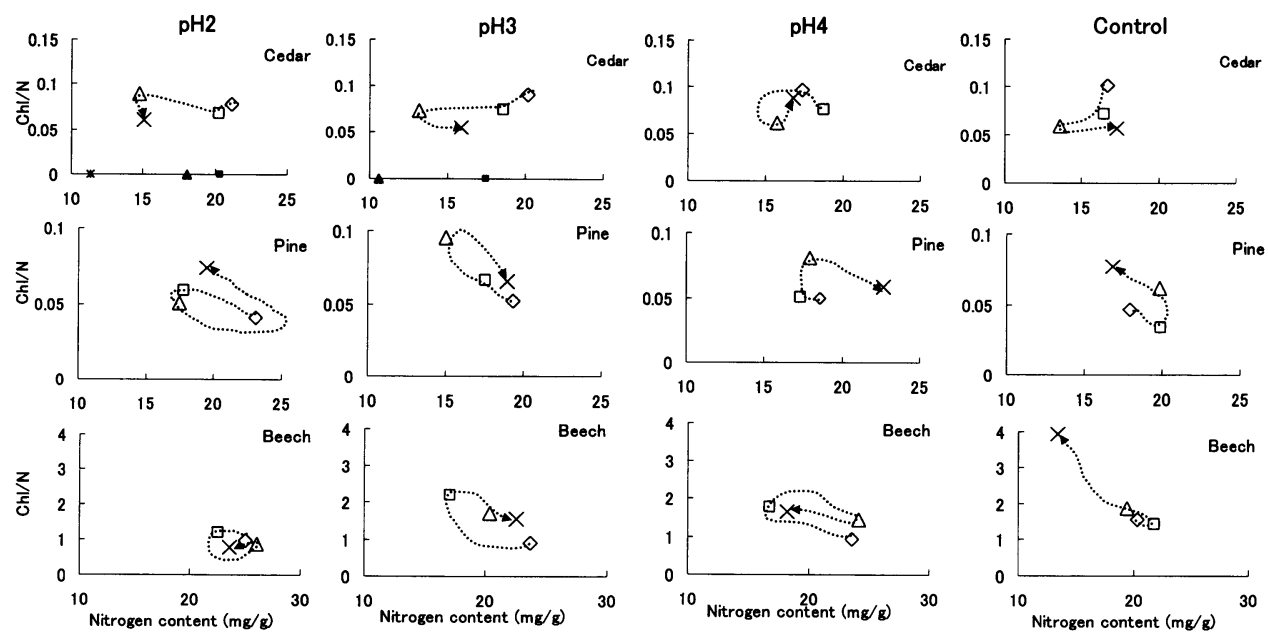

Fig. 7 Effects of simulated acid fog on the relationship between nitrogen content and chlorophyll to nitrogen content ratio $(\mathrm{Chl} / \mathrm{N})$ of leaves of cedar, pine and beech. 1, 2, 3 and 4-year-treatment are indicated by symbols of $\diamond, \square, \triangle$ and $\times$, respectively. $\boldsymbol{\square}, \boldsymbol{\Delta}$ and $*$ represent dead-plant leaf nitrogen content of 2, 3 and 4-year-treatment, respectively.

sis, the relationship between nitrogen content and chlorophyll to nitrogen content ratio (Chl/ $\mathrm{N}$ ) was investigated to clarify the long term effects of simulated acid fog (Fig. 7). Decrease in $\mathrm{Chl} / \mathrm{N}$ value indicates decrease in chlorophyll content even at high nitrogen availability, which ultimately results in low physiological activities.

\subsection{Beech}

In beech, $\mathrm{Chl} / \mathrm{N}$ for control plot gradually tended to move to the upper left corner which resulted in strong negative correlation. But for acid fog plots $\mathrm{Chl} / \mathrm{N}$ tended to decrease for all $\mathrm{pH}$ plots, especially that of 4-year-treatment, even though foliage nitrogen content was high in low acid fog plots (Fig. 7). The decrease was remarkable in $\mathrm{pH} 2$ plot for all duration of treated years. Nitrogen content in $\mathrm{pH} 2$ and $\mathrm{pH} 3$ plots tended to increase significantly comparing with the control.

\subsection{Cedar}

In cedar, nitrogen content to $\mathrm{Chl} / \mathrm{N}$ relationship showed different pattern in acid fog plots in comparison to the control plot but level of Chl/ $\mathrm{N}$ wasn't different in acid fog plots than in control plot. Nitrogen content in 1 and 2-year-treatment increased with decreasing acid fog $\mathrm{pH}$, which is from about $17 \mathrm{mgN} / \mathrm{g}$ dry weight in control plot to $21 \mathrm{mgN} / \mathrm{g}$ dry weight in $\mathrm{pH}$ 2 plot. But in 3 and 4-year-treatment nitrogen content didn't change (13-17 mgN/g dry weight) in low $\mathrm{pH}$ plots.

\subsection{Pine}

In case of pine too, $\mathrm{Chl} / \mathrm{N}$ didn't show any clear trend in all acid fog plots in comparison to the control. Nitrogen content of 1-year-treatment showed increasing trend with decreasing $\mathrm{pH}$, but no characteristic trend was found for other duration of treated year in all treatment plots.

\section{Visible injury}

\subsection{Cedar}

Visible foliar injury of cedar was observed on the needle tips of all acid fog $\mathrm{pH}$ plots, and late year needles showed much more injury than the current year needle. As for C98(3), 

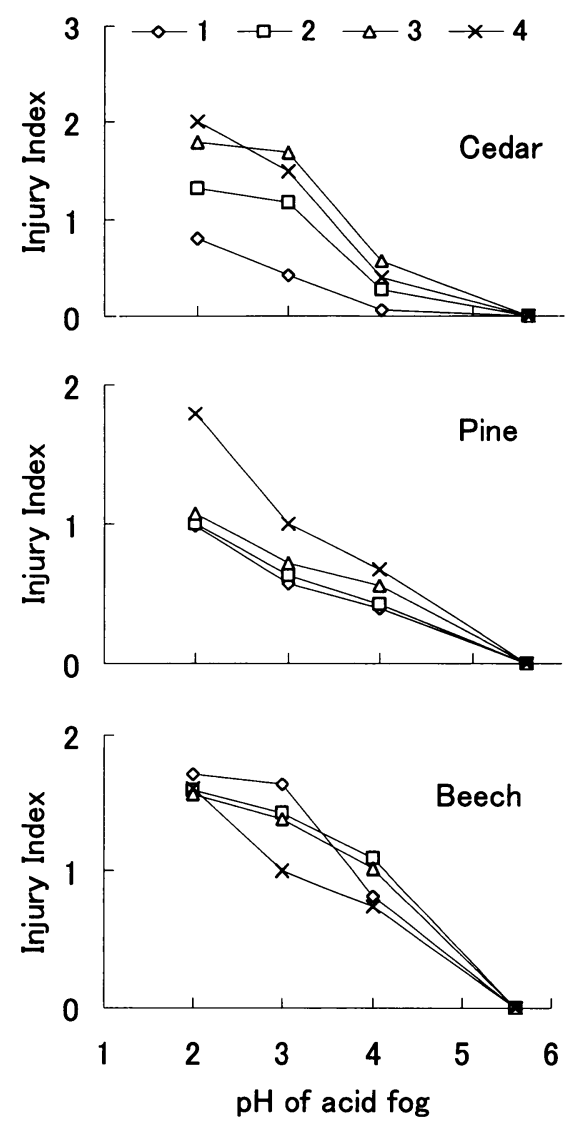

Fig. 8 Relationship between $\mathrm{pH}$ of acid fog and Injury Index. The values for same treatment years in Table 1 are averaged to draw this figure.

percentage of plant numbers in $\mathrm{pH} 2$ plot were 9, 9, 36 and 45\% in Injury Degree of 0, 1, 2 and 3 , respectively. Whereas those of $\mathrm{C} 00(1)$ were $10,25,25$ and $0 \%$, respectively. Similar trend was also found in all pH plots and all treated years in 2001 experiment. Thus, percentage of plant number in higher Injury Degree increased with decreasing $\mathrm{pH}$ and increasing duration of treated years. In the seedlings of C99(2) and C98(3) in 2000 and C98(4) in 2001, several plants of Injury Degree of 3 died. This indicates that 29 to $45 \%$ of plants died by acid fog exposure of $\mathrm{pH} 2$ and $\mathrm{pH} 3$.

Injury Index for 1-year-treatment increased with decreasing acid fog $\mathrm{pH}$ (Fig. 8). The tendency of more severe injury with increasing treated years and decreasing acid fog $\mathrm{pH}$ was found as shown in Fig. 8.

\subsection{Pine}

Visible foliar injury of pine was observed at first in $\mathrm{pH} 2$ and $\mathrm{pH} 3$ plots on the needle tips after about 1 month of exposure, and the injury gradually expanded towards the needle base as the exposure continued. The percentage of plant number in higher Injury Degree group increased with decreasing acid fog $\mathrm{pH}$ (Table 1). This result is the same as cedar, however no seedling died due to acid fog exposure. Injury Index in 1-year-treatment increased with decreasing acid fog $\mathrm{pH}$ (Fig. 8). Similar trend was observed for 2, 3 and 4-year-treatment and the increase became remarkable in 4-year-treatment. 
Table 1 Injury Degree for three species observed in 2000 and 2001 experiments and the Injury Index calculated by Eq. ( 1 ).

\begin{tabular}{|c|c|c|c|c|c|c|c|}
\hline \multirow{2}{*}{ Plant } & \multirow{2}{*}{ Plot } & \multirow{2}{*}{$n$} & \multicolumn{4}{|c|}{ Injury Degree } & \multirow{2}{*}{$\begin{array}{l}\text { Injury } \\
\text { Index }\end{array}$} \\
\hline & & & 0 & 1 & 2 & 3 & \\
\hline \multicolumn{8}{|c|}{2000 experiment } \\
\hline \multirow[t]{4}{*}{$\mathrm{COO}(1)$} & Control & 18 & $18(100)$ & & & & 0.00 \\
\hline & $\mathrm{pH} 4$ & 19 & $18(95)$ & $1(5)$ & & & 0.05 \\
\hline & pH 3 & 20 & $16(80)$ & $4(20)$ & & & 0.20 \\
\hline & $\mathrm{pH} 2$ & 20 & $10(50)$ & $5(25)$ & $5(25)$ & & 0.75 \\
\hline \multirow[t]{4}{*}{ C99(2) } & Control & 8 & $8(100)$ & & & & 0.00 \\
\hline & $\mathrm{pH} 4$ & 7 & $5(71)$ & $1(14)$ & $1(14)$ & & 0.43 \\
\hline & $\mathrm{pH} 3$ & 7 & $1(14)$ & $2(29)$ & $2(29)$ & $2(29)$ & 1.71 \\
\hline & $\mathrm{pH} 2$ & 13 & $2(15)$ & $3(23)$ & $4(31)$ & $4(31)$ & 1.77 \\
\hline \multirow[t]{4}{*}{ C98(3) } & Control & 8 & $8(100)$ & & & & 0.00 \\
\hline & $\mathrm{pH} 4$ & 7 & $6(86)$ & $1(14)$ & & & 0.14 \\
\hline & pH 3 & 10 & & $3(30)$ & $3(30)$ & $4(40)$ & 2.10 \\
\hline & $\mathrm{pH} 2$ & 11 & $1(9)$ & $1(9)$ & $4(36)$ & $5(45)$ & 2.18 \\
\hline \multirow[t]{4}{*}{ P00(1) } & Control & 19 & $19(100)$ & & & & 0.00 \\
\hline & pH 4 & 19 & $15(79)$ & $4(21)$ & & & 0.21 \\
\hline & $\mathrm{pH} 3$ & 19 & $13(68)$ & $6(32)$ & & & 0.32 \\
\hline & $\mathrm{pH} 2$ & 19 & $9(47)$ & $10(53)$ & & & 0.53 \\
\hline \multirow[t]{4}{*}{ P99(2) } & Control & 9 & $9(100)$ & & & & 0.00 \\
\hline & $\mathrm{pH} 4$ & 6 & $4(67)$ & $2(33)$ & & & 0.33 \\
\hline & pH 3 & 8 & $5(63)$ & $3(38)$ & & & 0.38 \\
\hline & $\mathrm{pH} 2$ & 12 & $6(50)$ & $4(33)$ & $2(17)$ & & 0.67 \\
\hline \multirow[t]{4}{*}{ P98(3) } & Control & 9 & $9(100)$ & & & & 0.00 \\
\hline & $\mathrm{pH} 4$ & 10 & $9(90)$ & $1(10)$ & & & 0.10 \\
\hline & pH 3 & 9 & $5(56)$ & $3(33)$ & $1(11)$ & & 0.56 \\
\hline & $\mathrm{pH} 2$ & 11 & $6(55)$ & $3(27)$ & $2(18)$ & & 0.64 \\
\hline \multirow[t]{4}{*}{$\mathrm{B} 00(1)$} & Control & 18 & $18(100)$ & & & & 0.00 \\
\hline & pH 4 & 20 & $5(25)$ & $6(30)$ & $9(45)$ & & 1.20 \\
\hline & pH 3 & 18 & & $5(28)$ & $13(72)$ & & 1.72 \\
\hline & $\mathrm{pH} 2$ & 19 & & $7(27)$ & $12(63)$ & & 1.63 \\
\hline \multirow[t]{4}{*}{ B99(2) } & Control & 10 & $10(100)$ & & & & 0.00 \\
\hline & $\mathrm{pH} 4$ & 11 & $1(9)$ & $7(64)$ & $3(27)$ & & 1.18 \\
\hline & pH 3 & 9 & & $3(33)$ & $6(67)$ & & 1.67 \\
\hline & $\mathrm{pH} 2$ & 9 & & $2(22)$ & $8(89)$ & & 1.80 \\
\hline \multirow[t]{4}{*}{ B98(3) } & Control & 7 & $7(100)$ & & & & 0.00 \\
\hline & $\mathrm{pH} 4$ & 7 & $1(14)$ & $2(29)$ & $4(57)$ & & 1.43 \\
\hline & $\mathrm{pH} 3$ & 9 & & $4(44)$ & $5(56)$ & & 1.56 \\
\hline & $\mathrm{pH} 2$ & 9 & & $2(22)$ & $7(78)$ & & 1.78 \\
\hline \multicolumn{8}{|c|}{2001 experiment } \\
\hline \multirow[t]{4}{*}{ C01(1) } & Control & 14 & $14(100)$ & & & & 0.00 \\
\hline & pH 4 & 14 & $13(93)$ & $1(7)$ & & & 0.07 \\
\hline & pH 3 & 14 & $5(36)$ & $9(64)$ & & & 0.64 \\
\hline & $\mathrm{pH} 2$ & 8 & $2(25)$ & $5(63)$ & $1(13)$ & & 0.88 \\
\hline \multirow[t]{4}{*}{$\mathrm{COO}(2)$} & Control & 10 & $10(100)$ & & & & 0.00 \\
\hline & pH 4 & 9 & $8(89)$ & $1(11)$ & & & 0.11 \\
\hline & $\mathrm{pH} 3$ & 8 & $4(50)$ & $3(38)$ & $1(13)$ & & 0.63 \\
\hline & $\mathrm{pH} 2$ & 7 & $2(29)$ & $4(57)$ & $1(14)$ & & 0.86 \\
\hline \multirow[t]{4}{*}{ C99(3) } & Control & 4 & $4(100)$ & & & & 0.00 \\
\hline & $\mathrm{pH} 4$ & 4 & & $4(100)$ & & & 1.00 \\
\hline & pH 3 & 4 & & $3(75)$ & $1(25)$ & & 1.25 \\
\hline & $\mathrm{pH} 2$ & 5 & & $3(60)$ & $2(40)$ & & 1.40 \\
\hline
\end{tabular}


Table 1 (continued).

\begin{tabular}{|c|c|c|c|c|c|c|c|}
\hline \multirow{2}{*}{ Plant } & \multirow{2}{*}{ Plot } & \multirow{2}{*}{$n$} & \multicolumn{4}{|c|}{ Injury Degree } & \multirow{2}{*}{$\begin{array}{l}\text { Injury } \\
\text { Index }\end{array}$} \\
\hline & & & 0 & 1 & 2 & 3 & \\
\hline \multirow[t]{4}{*}{ C98(4) } & Control & 5 & $5(100)$ & & & & 0.00 \\
\hline & $\mathrm{pH} 4$ & 5 & $3(60)$ & $2(40)$ & & & 0.40 \\
\hline & pH 3 & 6 & & $3(50)$ & $3(50)$ & & 1.50 \\
\hline & pH 2 & 6 & & $2(33)$ & $2(33)$ & $2(33)$ & 2.50 \\
\hline \multirow[t]{4}{*}{ P01(1) } & Control & 11 & $11(100)$ & & & & 0.00 \\
\hline & $\mathrm{pH} 4$ & 9 & $4(44)$ & $5(56)$ & & & 0.56 \\
\hline & $\mathrm{pH} 3$ & 10 & $4(40)$ & $4(40)$ & $2(20)$ & & 0.80 \\
\hline & $\mathrm{pH} 2$ & 9 & & $5(56)$ & $4(44)$ & & 1.44 \\
\hline \multirow[t]{4}{*}{$\mathrm{P} 00(2)$} & Control & 8 & $8(100)$ & & & & 0.00 \\
\hline & $\mathrm{pH} 4$ & 8 & $4(50)$ & $4(50)$ & & & 0.50 \\
\hline & $\mathrm{pH} 3$ & 7 & $2(29)$ & $4(57)$ & $1(14)$ & & 0.86 \\
\hline & $\mathrm{pH} 2$ & 6 & & $4(67)$ & $2(33)$ & & 1.33 \\
\hline \multirow[t]{4}{*}{ P99(3) } & Control & 5 & $5(100)$ & & & & 0.00 \\
\hline & pH 4 & 5 & & $5(100)$ & & & 1.00 \\
\hline & $\mathrm{pH} 3$ & 8 & $2(25)$ & $5(63)$ & $1(13)$ & & 0.88 \\
\hline & $\mathrm{pH} 2$ & 4 & & $2(50)$ & $2(50)$ & & 1.50 \\
\hline \multirow{4}{*}{ P98(4) } & Control & 5 & $5(100)$ & & & & 0.00 \\
\hline & $\mathrm{pH} 4$ & 3 & & $3(100)$ & & & 1.00 \\
\hline & $\mathrm{pH} 3$ & 6 & $2(33)$ & $4(67)$ & & & 0.67 \\
\hline & pH 2 & 5 & & $1(20)$ & $4(80)$ & & 1.80 \\
\hline \multirow[t]{4}{*}{ B01(1) } & Control & 7 & $7(100)$ & & & & 0.00 \\
\hline & $\mathrm{pH} 4$ & 11 & $7(64)$ & $3(27)$ & $1(9)$ & & 0.45 \\
\hline & $\mathrm{pH} 3$ & 11 & & $5(45)$ & $6(55)$ & & 1.55 \\
\hline & $\mathrm{pH} 2$ & 9 & & $2(22)$ & $8(89)$ & & 1.80 \\
\hline \multirow[t]{4}{*}{$\mathrm{B} 00(2)$} & Control & 8 & $8(100)$ & & & & 0.00 \\
\hline & $\mathrm{pH} 4$ & 9 & $1(11)$ & $7(78)$ & $1(11)$ & & 1.00 \\
\hline & $\mathrm{pH} 3$ & 6 & & $5(83)$ & $1(17)$ & & 1.17 \\
\hline & $\mathrm{pH} 2$ & 8 & & $5(63)$ & $3(38)$ & & 1.38 \\
\hline \multirow[t]{4}{*}{ B99(3) } & Control & 6 & $6(100)$ & & & & 0.00 \\
\hline & $\mathrm{pH} 4$ & 5 & $2(40)$ & $3(60)$ & & & 0.60 \\
\hline & $\mathrm{pH} 3$ & 5 & & $4(80)$ & $1(20)$ & & 1.20 \\
\hline & $\mathrm{pH} 2$ & 6 & & $4(67)$ & $2(33)$ & & 1.33 \\
\hline \multirow[t]{4}{*}{ B98(4) } & Control & 4 & $4(100)$ & & & & 0.00 \\
\hline & $\mathrm{pH} 4$ & 4 & $1(25)$ & $3(75)$ & & & 0.75 \\
\hline & $\mathrm{pH} 3$ & 8 & $2(25)$ & $4(50)$ & $2(25)$ & & 1.00 \\
\hline & $\mathrm{pH} 2$ & 5 & & $2(40)$ & $3(60)$ & & 1.60 \\
\hline
\end{tabular}

Cedar, pine and beech seedlings are indicated by $\mathbf{C}, \mathbf{P}$ and $\mathbf{B}$. Numerals suffix after $\mathrm{C}, \mathrm{P}$ and $\mathrm{B}$ represent the year that seedlings are started to expose by acid fog treatment, and numbers in the parentheses represent duration of treated years. $n$ indicates total number of plants in each treatment plot. Numbers in parentheses indicate percentage of total plant number in the group of each Injury Degree. Plots where Injury Degree wasn't observed are left blank.

\subsection{Beech}

Beech seedlings of $\mathrm{pH} 2$ treatment showed visible foliar injury symptoms within one week after the treatment in every year. Symptoms appeared from leaf edge, including discoloration and brown stippling that later turned bigger and covered the entire surface of the leaf until leaf shed occurred. Beech also showed the tendency of increase in percentage of plant number with higher Injury Degree in low pH plots (Table 1). Injury Index of 1-year-treatment tended to increase with decreasing acid fog $\mathrm{pH}$. Similar trend was also observed for longer duration 
of treated years, but Injury Index didn't increase than those in 1-year-treatment plot (see Fig. 8). Thus, although the Injury Index increased with decreasing $\mathrm{pH}$ it was clear that treated duration doesn't affect the pH-Injury Index relationship.

\section{DISCUSSION}

\section{Effects on foliage chlorophyll and nitrogen content ratio}

For beech (Fig. 7), as in control plot, normally, relationship between foliage $\mathrm{N}$ content and $\mathrm{Chl}$ and nitrogen contents ratio $(\mathrm{Chl} / \mathrm{N})$ was found to have negative correlation $(r=-$ 0.99). Similar negative correlation was also found for $\mathrm{pH} 4(r=-0.79)$ and $\mathrm{pH} 3(r=-0$. 93) plots with lower $\mathrm{Chl} / \mathrm{N}$. Whereas in $\mathrm{pH} 2$ plot $(r=-0.5), \mathrm{Chl} / \mathrm{N}$ decreased with increase in foliage nitrogen content and gathered into the range of $22-26 \mathrm{mgN} / \mathrm{g}$ dry weight for all duration of treated years. This suggests that, balance of foliage nitrogen content and Chl content in beech lowered photosynthesis, ultimately resulting in low dry matter production. Pine showed slightly decreased $\mathrm{Chl} / \mathrm{N}$ in $\mathrm{pH} 2$ and $\mathrm{pH} 3$ plots except 4-year-treatment. Conversely, cedar showed slightly decreasing trend of nitrogen content for 3 and 4-yeartreatment, however $\mathrm{Chl} / \mathrm{N}$ remained constant although both chlorophyll and nitrogen contents showed decreasing trend. From this result it can be said that in case of cedar and pine, chlorophyll and nitrogen contents may not be affected by acid fog $\mathrm{pH}$ in short-term experiments. But death of cedar seedlings in $\mathrm{pH} 3$ and $\mathrm{pH} 2$ plots as the result of accumulation of effects by acid fog shows that cedar is susceptible to long-term effects of low $\mathrm{pH}$ acid fog. This result also shows differences in susceptibility by acid fog exposure in cedar, pine and beech.

\section{Effects on visible injury}

As shown in Fig. 8, Injury Index of cedar remarkably increased with increasing duration of treated years. Whereas in pine, Injury Index remained almost the same until 3-yeartreatment, but remarkable increase of Injury Index was found in 4-year-treatment. In contrast, Injury Index of beech didn't increase with increasing duration of treated years until 4 years. This can be explained by the fact that no leaf shedding occurs in cedar throughout the branch lifetime, but beech plants renew leaves every year, while pine needles don't shed until 3 year. Based on this pattern of leaf shedding, it can be said that cedar tends to accumulate the effect of acidic deposition inside the plant body which explains the increase in foliar injury and ultimate death of seedlings in 2, 3 and 4-year-treatment.

\section{Effects on growth}

TDW of pine and cedar in $\mathrm{pH} 2$ and/or $\mathrm{pH} 3$ plots increased with increasing duration of treated years, but TDW of beech showed decreasing trend with decreasing acid fog $\mathrm{pH}$ and with increasing duration of treated years. This suggests low $\mathrm{pH}$ acid fog induces growth enhancement in cedar and pine. Rayle and Cleland (1977) proposed that $\mathrm{H}^{+}$in acid rain stimulates the growth possibly by expansion of bonds during cell wall extension stage. Other reports have shown that growth stimulation by acid rain may be caused by $\mathrm{NO}^{3-}$ fertilization (Lee and Weber, 1979). In this experiment, especially, late year needles of cedar in pH 3 plot showed significantly enhanced growth as shown in Fig. 4. Jagels et al. (2002) have also proved the increase in needle dry weight by nitrogen from ammonium ions and/or nitrate. Pine, which is also evergreen tree didn't show enhanced needle dry weight growth. Instead, stem growth was significantly high in pH 2 plot. Wood and Bormann (1976) showed that stimulation in growth doesn't continue for long time. In this experiment also, some of the cedar seedlings treated by extremely acidic fog in 2000 and 2001 experiments died (see Table 1). The reason that the death of seedlings was observed only in cedar may be because of the 
lack of leaf shedding.

In beech, however, dry weight of each organ as well as TDW showed inhibited growth with decreasing acid fog $\mathrm{pH}$. Longer the duration of treated year, greater was the decrease in TDW for all treatment plots. This shows that the growth of deciduous trees is remarkably inhibited by long-term exposure to acid fog.

\section{Effects of $\mathrm{Chl} / \mathrm{N}$ and visible injury on growth}

In cedar, foliage nitrogen content gradually decreased by acid fog exposure, and decrease in growth was found for 2 and 4-year-treatment. This growth decrease may be attributed to decrease in foliage nitrogen content which results in reduction of photosynthetic pigments. This may have ultimately led to the death of cedar seedlings mentioned above. In pine, characteristic changes in foliage chlorophyll, nitrogen content and $\mathrm{Chl} / \mathrm{N}$ wasn't observed. In addition, growth of pine tended to be enhanced by acid fog $\mathrm{pH}$ up to 4-year-treatment. This fact may show tolerance of pine to low $\mathrm{pH}$ acid fog. But, increase in Injury Index for 4-year-treatment shows negative effects of long-term exposure by acid fog is inevitable. On the contrary to both cedar and pine, beech showed significant reduction in growth with decreasing $\mathrm{pH}$ and increasing duration of treated year. This would be attributed to the severe visible injury from the first year of experiment.

\section{Concluding Remarks}

From this experiment it can be concluded that effects of simulated acid fog on tree seedlings are quite complex, and differences in plant response to simulated acid fog was found depending on tree species and duration of treated years. Moreover, results showed that the effects of acid fog on coniferous tree seedlings are comparatively small in short-term experiments. However, long-term exposure to acid fog would result in death as found in cedar, and severe growth reduction as found in beech. Thus, longer experiments become necessary to verify the effects of acid fog on forest decline.

\section{REFERENCES}

Aboal, J. R., Fernandez, J. A., Carballeira, A. 2001. Sampling optimization, at site scale, in contamination monitoring with moss, pine and oak. Environ. Pollut. 115 : 313-316.

Abouguendia, Z. M., Baschak, L. A. 1987. Response of two western Canadian conifers to simulated acidic precipitation. Water Air Soil Pollut. 33: 15-22.

Arnon, D. I. 1949. Copper enzymes in isolated chloroplasts. Polyphenoloxidase in Beta vulgaris. Plant Physiol. 24 : 1-15

Ashenden, T. W., Bell, S. A. 1988. Growth response of birch and Stika spruce exposed to acidified rain. Environ. Pollut. 51 : 153-162.

Back, J., Neuvonen, S., Huttunen, S. 1994. Pine needle growth and fine structure after prolonged acid rain treatment in the subarctic. Plant Cell Environ. 17: 1009-1021.

Boyce, R. L., McCune, D. C., Berlyn, G. P. 1991. A comparison of foliar wettability of red spruce and balsam fir growing at high elevation. New Phytol. 117 : 543-555.

Cape, J. N., Leith, I. D., Fowler, D., Murray, M. B., Sheppard, L. J., Eamus, D., Wilson, R. H. F. 1991. Sulphate and ammonium mist impair the frost hardening of red spruce seedlings. New Phytol. 119: 119-126.

Eamus, D., Fowler, D. 1990. Photosynthetic and stomatal conductance responses to acid mist of red spruce seedlings. Plant Cell Environ. 13 : 349-357.

Fan, B. H., Wang, Y. H. 2000. Effects of simulated acid rain on germination, foliar damage, chlorophyll contents and seedling growth of five hardwood species growing in China. For. Eco. Manag. 126 : 321329. 
Jacobson, J. S., Heller, L. I., Yamada, K., Osmeloski, J., Behtard, T., Lassoie, J. P. 1990b. Foliar injury and growth response of red spruce to sulphate and nitrate acidic mist. Can. J. For. Res. 20: 58-65.

Jagels, R., Jiang, M., Marden, S., Carlisle, J. 2002. Red spruce canopy response to acid fog exposure. Atm. Res. 64 : 169-178.

Jiang, M., Jagels, R. 1999. Detection and qualification of changes in membrane-associated calcium in red spruce sapling exposed to acid fog. Tree Physiol. 19 : 909-916.

Kytoviita, M., Fritze, H., Neuvonen, S. 1990. The effects of acidic irrigation on soil microorganisms at Kevo, Northern Finland. Environ. Pollut. 66 : 21-31.

Lee, J. J., Weber, D. E. 1979. The effect of simulated acid rain on seedling emergence and growth of eleven woody species. For. Sci. 25 : 393-398.

Leith, I. D., Sheppard, L. J., Cape, J. N., Deans, J. D., Smith, R. I., Fowler, D. 1989. Visible foliar injury of red spruce seedlings subjected to simulated acid mist. New Phytol. 113 : 313-320.

Momen, B., Anderson, P. D., Houpis, J. L. J., Helms, J. A. 2002. Growth of ponderosa pine seedlings as effected by air pollution. Atm. Env. 36: 1875-1882.

Percy, K. 1986. The effects of simulated acid rain on germinative capacity, growth and morphology of forest tree seedlings. New Phytol. 104 : 473-484.

Rayle, D. L., Cleland, R. 1977. Control of plant cell enlargement by hydrogen ions. Curr. Top. Dev. Biol. 11 : 187-214.

Schutt, P., Cowling, E. B. 1985. Waldsternben, a general decline of forest in central Europe ; symptoms ; development and possible causes. Plant Dis. 69 : 548-558.

Thelin, G., Rosengren, U., Callesen, I., Ingerslev, M. 2002. The nutrient status in Norway spruce in pure and in mixed-species stands. For. Eco. Manag. 160: 115-125.

Treshow, M., Anderson, F. K. 1989. Plant Stress from Air Pollution. John Wiley \& Sons, Chichester.

Turner, D. P., Tingey, D. T. 1990 . Foliar leaching and root uptake of $\mathrm{Ca}, \mathrm{Mg}$ and $\mathrm{K}$ in relation to acid fog effects on Douglas-fir. Water Air Soil Pollut. 49: 205-214.

Wood, T., Bormann, F. H. 1976. Short-term effects of simulated acid rain upon the growth and nutrient relations of Pinus strobes L. In "Proc. 1st Int. Symp. on Acid Precipitation and the Forest Ecosystem" (ed. by Dochinger, L. S., Seliga, T. A.), U.S.D.A. Forest Service, Gen. Tech. Rep. No. NE-23, Upper Darby, Pennsylvania, p 815-826. 